\title{
Haiti: Aspectos Socio-Históricos Internos e Emigração
}

Recebido: 08-02-2018

Aprovado: 26-06-2018

Simone Rodrigues Pinto*

\section{Introdução}

Existe um enorme desconhecimento no Brasil sobre esse país que já foi considerado a pérola das Antilhas, lar da civilização do Taínos, lugar do primeiro assentamento espanhol no Novo Mundo, passagem dos famosos galeões espanhóis transportando as riquezas espoliadas dos impérios asteca e inca, lugar do legendário paraíso dos piratas, a ilha Tortuga, e inferno dos escravos negros trazidos do continente africano e submetidos ao sistema mais brutal de escravidão de todas as Américas. Enaltecido como primeira república negra do mundo, segunda colônia a se tornar independente no continente, viveu terríveis massacres e genocídios e padeceu sob uma brutal elite local, prefigurada em ditadores sanguinários como Papa Doc e Baby Doc. Apesar de um orgulho pela ancestralidade africana, convive em sua cultura uma intensa aspiração pelos costumes norte-americanos e franceses, às vezes travestidos de sentimento anti-americano e anti-francês, que transformam esses países em sonho de destino ao mesmo tempo que o intenso desejo de emigrar convive com um profundo orgulho de ser haitiano.

O terremoto que arrasou a capital do Haiti, Porto Príncipe, em 2010 foi um daqueles eventos fortuitos que têm o poder de trazer a tona o pior e o melhor das instituições e das pessoas. O desenrolar dos eventos após o choque inicial serve de laboratório para entender a principal tensão que afeta o país desde a sua colonização: a desesperada necessidade por ajuda

\footnotetext{
* Professor do Departamento de Estudos Latino-Americanos, Doutora em Ciência Política, Brasileira, e-mail para contato: smartinsrodrigues@ hotmail.com. Áreas de atuação: direitos humanos, políticas de reconhecimento e multiculturalismo; medidas restaurativas na solução de controvérsias entre indígenas na América Latina, com foco no pluralismo jurídico; autoritarismos, justiça de transição, memória, verdade e reparação na América Latina; pensamento social e político latino-americano.
} 
internacional e sua profunda desconfiança em relação aos estrangeiros que se dizem simpatizantes e portadores de ajuda. A trajetória histórica deste pequeno país, localizado na parte oeste da importante ilha de Hispaniola, demonstra que ajuda humanitária nem sempre pode ser adjetivada desta forma.

Esta mesma tensão se apresenta no imaginário individual e social de sua população, traduzido por um fascínio pelos Estados com os quais têm relações de dominação ou rivalidade como EUA, França e República Dominicana, por exemplo, ao mesmo tempo em que temem o risco constante de suas políticas imperialistas. Não por acaso, estes países representam o principal destino dos migrantes haitianos, ao mesmo tempo em que apresentam as políticas migratórias mais restritivas.

Para compreender esse arranjo social é preciso um olhar ao passado sócio-histórico desta nação. Após um terremoto de proporções catastróficas, muitas declarações buscaram reavivar antigos preconceitos contra o Haiti, principalmente requentando ligação entre a prática do vodu e as sucessivas tragédias que atingem o país. O pastor evangélico norteamericano Pat Robertson afirmou que o país vivia as consequências do pacto com o diabo, feito durante a guerra de independência dois séculos antes ${ }^{1}$. No entanto, podemos compreender o abalo a partir de uma explicação mais prosaica: o Haiti está situado sobre a junção de três placas tectônicas. Ainda, há explicações mais dramáticas, como a falta de adequada estrutura das edificações ${ }^{2}$, que são construídas com muita economia de cimento e ferro e instituições extremamente frágeis que não foram capazes de socorro rápido.

Neste cenário-laboratório, as primeiras nações a enviar ajuda foram justamente França, EUA e República Dominicana. Ainda que os principais comandantes norteamericanos enviados ao Haiti fossem negros, a imagem dos helicópteros Black Hawk circulando o palácio presidencial trazia de volta as dolorosas memórias da ocupação dos EUA nos anos 1915-1934 e 1994-2000. Nem os apelos do primeiro ministro Jean-Max Bellerive, afirmando as boas intensões do vizinho do norte, afastaram os rumores de nova intervenção. Mesmo o jornal mais conservador, ligado à comunidade haitiana nos EUA, o Haiti Observateur, reafirmou "risk inherent in any intervention of this kind" pressão dos Republicanos para continuar uma política mais imperialista. Estas afirmações não

\footnotetext{
${ }^{1} \mathrm{O}$ marco inicial da guerra de independência foi a reunião liderada pelo sacerdote vodu Bookman.

${ }^{2}$ Quatorze meses antes do abalo, noventa crianças morreram com um desabamento de uma escola próxima a Petiónville, sem a presença de nenhum abalo sísmico.

${ }^{3}$ Leslie Péan, "Obama pris entre deux feux et Haiti”, Haiti Observateur, Fevereiro 3-10, 2010, p.8.
} 
são de todo descabidas. O senador por Connecticut Christopher Dodd evocou a possibilidade de transformar o Haiti em protetorado dos EUA ou "some sort of international receivership".

São muitos os paradoxos. Uma sociedade fundada, constitucionalmente, na igualdade entre negros e brancos, vive no cotidiano uma cruel divisão racial entre negros e mulatos, uma complexa relação com os estrangeiros e, apesar da imensa riqueza geográfica e cultural, fraqueza e corrupção institucional, além de uma brutal ingerência externa, paralisam seu desenvolvimento. Este texto se propõe a uma breve análise sócio-histórica, centrada em fatores internos, explanada de forma cronológica e linear para facilitar o encadeamento dos eventos, a fim de dar subsídios para a compreensão de alguns desses paradoxos e dos motivos do grande número de haitianos que emigram deste país.

Fatores externos, como a dominação imperialista dos EUA sobre a região, são importantes na compreensão de muitos processos. No entanto, esse texto não pretende aprofundar na geopolítica internacional, mas lançar luz sobre fatores endógenos da emigração haitiana. Apesar de ser um enfoque reconhecidamente limitado, é fundamental para a compreensão do cenário mais amplo que acerca o Haiti.

\section{Período Colonial}

O período colonial pode ser considerado particularmente importante para a compreensão da realidade haitiana ainda hoje. Não só porque representa três séculos dos cinco passados desde a chegada de Colombo, mas também porque impactou todo o desenrolar da história sócio-política do Haiti pós-colonial. O país experimentou os dois sistemas coloniais mais duros da época, primeiro o espanhol, depois o francês. A Espanha, em pouco mais de dez anos, extraiu aproximadamente quinze mil toneladas de ouro, depois de exterminar os indígenas nativos. As plantações de cana-de-açúcar foram exploradas ao máximo em benefício do desenvolvimento da metrópole francesa, a partir de um dos sistemas escravistas mais violentos dessa era, que representava um terço da economia francesa da época (Hurbon, 1972)

Quando Cristóvão Colombo chegou em 1492 ao Caribe, rumou para o sul em busca de ouro e especiarias. Logo ocupou a ilha que chamou de Hispaniola, onde havia cerca de meio

\footnotetext{
${ }^{4}$ https://www.c-span.org/video/?291699-1/haiti-earthquake-relief-efforts
} 
milhão de indígenas Taínos. Duas gerações depois, os nativos haviam praticamente desaparecido, vítimas da violência espanhola ou de doenças estrangeiras para as quais não estavam preparados. Diante das riquezas do Império Asteca e do Império Inca e da falta de mão-de-obra indígena a ser explorada, no século XVII a ilha foi perdendo interesse no mercado mundial da exploração colonial. Quase nada havia sobrado da civilização nativa, além de poucas palavras no vocabulário local como huracán, barbacoa e tabaco. A despeito das denúncias feitas por Bartolomeu de Las Casas, o extermínio dos Taínos foi praticamente total.

O pouco interesse dos espanhóis pela agora chamada Santo Domingo permitiu que alguns assentados franceses avançassem sobre o território. Muitos caçavam porcos selvagens que cozinhavam ao estilo taíno nos fornos chamados de boucan, os quais vendiam aos navios que passavam. Daí surgiram os primeiros boucaniers, ou bucaneiros. (Girard, 2010, p.21). Logo, estes cozinheiros descobririam que roubar os navios espanhóis cheios de riquezas do Novo Mundo era mais lucrativo que caçar porcos. Apoiados pelo governo francês, tornaramse mercenários ladrões de navios carregados de riquezas que iam em direção à Europa. Depois que a França oficializou seu domínio sobre a parte ocidental da ilha por meio do Tratado de Ryswick de 1697, dividindo a ilha nos atuais países Haiti e República Dominicana, a presença dos bucaneiros já não era bem-vinda. De ladrões apoiados pelo Estado, passaram à ilegalidade. A maioria fugiu para a ilha de Tortuga, onde foi estabelecido um estado pirata independente, liderado inicialmente pelo ditador francês Jean le Vasseur, há poucos quilômetros ao norte da agora Saint Domingue ${ }^{5}$. O antigo Haiti não era mais lar desses tipos de piratas, mas de outra casta de exploradores.

Depois do massacre e extinção quase completa dos nativos, Saint Domingue viveu um dos regimes escravistas mais cruéis das Américas. O país era conhecido por proporcionar enriquecimento rápido, mas também famoso pelas doenças tropicais e pela dureza das fazendas de cana-de-açúcar. O açúcar era o petróleo da época, produto cobiçado pelos principais países da Europa, e Saint Domingue, pelo seu tamanho e clima, um dos mais lucrativos produtores desta preciosidade. Ao contrário das plantações de café, o açúcar demandava um grande número de trabalhadores e condições difíceis de cultivo. O perigo dos facões que provocavam frequentemente mutilações, as folhas cortantes que faziam a pele

\footnotetext{
${ }^{5}$ Para fazer referência ao Haiti colonial, o texto usará seu nome em francês Saint Domingue, em contraposição ao país a leste da ilha, Santo Domingo, colônia espanhola.
} 
arder com o suor do trabalho, cobras, insetos e, ainda, o calor adicionado ao clima tropical das enormes caldeiras de caldo de cana fervente. Os trabalhadores europeus morriam às centenas.

A solução, proposta ironicamente pelo defensor dos indígenas Bartolomeu de Las Casas, foi a importação de mão-de-obra africana, a quem foi atribuída maior força e resistência. No início, em 1700, chegaram cerca de nove mil escravos a Saint Domingue. Em 1790, a colônia importou 48 mil só nesse ano, elevando a população de escravos para 500 mil (Girard, 2010). Eles também morriam aos milhares, mas suas vidas simplesmente importavam menos que as dos trabalhadores europeus. Eles eram rapidamente substituídos por novas levas de escravos vindos em grandes navios de tráfico negreiro. Comparado com os EUA, a pequena ilha de Saint Domingue, que aboliu a escravidão setenta anos antes que o vizinho do norte, importou bem mais escravos, que tinham uma expectativa de vida que mal chegava a 10 anos. Enquanto nos EUA ou no Brasil as condições permitiam que se reproduzissem, em Saint Domingue não viviam para tanto.

Apesar deste barril de pólvora prestes a explodir, a primeira tentativa de independência partiu dos brancos proprietários e mulatos livres. Como toda colônia da época, a população local tinha pouca autonomia decisória e o monopólio comercial imposto pela metrópole gerava revolta. Quando ocorre a Revolução Francesa em 1789, a população local branca passa a se mobilizar para garantir a independência da ilha e o controle da vida política. (James, 1989) Os mulatos se unem para reivindicar a igualdade proposta pela Declaração de Direitos francesa. A esta altura, ninguém mencionava a possibilidade de fim do regime escravista.

Os mulatos Vincent Ogé e Julien Raimond chegaram a ir perante a Assembleia Nacional em Paris para pedir igualdade de direitos, sem nada conseguir. Ao retornar a Saint Domingue iniciaram uma rebelião que terminou com a tortura e morte brutal de Vincent Ogé. Enquanto mulatos livres e brancos, ambos proprietários de escravos, lutavam entre si, a verdadeira rebelião estava por acontecer entre os negros escravos.

Na noite de 21 de agosto de 1791, escravos representantes de quase todo o norte do Haiti se reuniram em Bois Caiman, liderados pelo sacerdote vodu Dutty Boukman. Quando todos chegaram, Cécile Fatiman, uma sacerdotisa vodu degolou um porco e a partir daí todos se comprometeram com Ogun a vingar o sofrimento dos negros matando seus senhores. Para selar esse pacto sagrado beberam sangue e fizeram talismãs de proteção com os pelos do 
porco (Dubois e Garrigus, 2006). Quando voltaram às suas plantações, a revolução haitiana começou. Centenas de proprietários foram mortos e suas plantações incendiadas.

O vodu, parte importante da cultura haitiana, a despeito dos mitos e lendas sobre sua prática, representa o sincretismo entre uma religião politeísta emprestada da África ocidental com o misticismo católico da França dos séculos XVII e XXVIII. Muitos proprietários franceses, seguindo uma paixão francesa pelo ocultismo na época, faziam encantamentos e rituais ocultistas em suas plantações na presença de seus escravos. Muitas dessas práticas foram absorvidas nas cerimônias vodus junto com as tradições religiosas dos ancestrais africanos. Mesmo depois da independência do Haiti, o vodu continuou uma religião proscrita, ainda que haja rumores de que era praticada pela maioria dos líderes em secreto. Toussaint Louverture, Jean-Jacques Dessalines, Henri Christophe e Jean-Pierre Boyer condenavam publicamente as cerimônias vodu, que só foram liberadas em 1846. E depois mais uma vez proibidas com a invasão dos EUA em 1915. (Hurbon, 1972)

Durante a revolta, pedidos de ajuda foram feitos a Cuba, Jamaica, Santo Domingo e aos EUA, mas poucos atenderam. $\mathrm{O}$ exército francês conseguiu arrebanhar alguns escravos leais e mulatos livres sob a promessa de igualdade futura. Dessa forma, em 1792 grande parte da revolta já tinha sido controlada, alguns negros estavam de volta a suas plantações ou haviam fugido para as montanhas.

Em 1793, os revolucionários franceses levam Louis XVI à guilhotina, provocando uma forte reação de outros países da Europa. A guerra das monarquias europeias contra a França faz com que menos atenção seja dada aos problemas de suas colônias além mar. Logo, Inglaterra e Espanha invadem Saint Domingue, a primeira a partir do maior porto da colônia e a segunda através da fronteira com Santo Domingo. Certamente, nenhuma das duas potências coloniais tinha a intenção de libertar os escravos, oferecendo pouca vantagem na troca de metrópoles. Dessa forma, quando a França envia um novo comissionado comprometido com os ideais de igualdade, fraternidade e liberdade da Revolução Francesa, expressamente antiescravista, Léger-Félicité Sonthonax, os negros revoltosos têm uma janela de oportunidade. Sonthonax oferece imediata emancipação para os escravos em troca de ajuda militar para expulsar as tropas britânicas e espanholas do território. Esta decisão é confirmada por Paris, que estende a abolição da escravidão a Guadalupe, tornando-se a primeira metrópole europeia a emancipar seus escravos na América. Neste momento, o já destacado líder negro Toussaint Louverture, que lutava ao lado dos espanhóis, muda de lado e passa a compor o contingente 
francês. Depois de violentas batalhas, Inglaterra e Espanha finalmente são derrotadas em 1798.

Toussaint Louverture é a personagem mais reconhecida e celebrada da história do Haiti, apesar de não livre de controvérsias. (Dubois, 2004). Filho de um rei africano, foi levado a Saint Domingue, onde trabalhou como cocheiro, ficando livre do trabalho extenuante da plantação. Ainda como escravo, foi alfabetizado e recebeu de seu dono a alforria mais de uma década antes da revolução. Quando a revolta iniciou, Louverture, que era dono de uma pequena propriedade e de cerca de treze escravos, protegeu seus antigos proprietários antes de se juntar às tropas revoltosas. Inteligente e sagaz, logo subiu na hierarquia dos rebeldes, depois na hierarquia das tropas espanholas e, depois, na hierarquia das tropas francesas. Com a derrocada dos britânicos, Louverture passa a ser a mais importante figura militar na ilha. Logo fez manobras políticas para que Sonthonax voltasse para Paris, como representante de Saint Domingue, guerreou contra André Rigaud, um mulato que controlava o sul do país e afastou seus supostos aliados Gabriel d'Hedouville e Julien Raimond, removendo qualquer obstáculo à sua chegada ao poder. (Césaire, 2004). Em 1801, Louverture promulga unilateralmente uma constituição que o transforma em governador geral vitalício com direito a nomear seu sucessor. Apesar de reinar soberano na ilha, não reivindicou a independência do país. Sua constituição vai se tornar a primeira constituição do país independente em 1805 e se tornará um marco na compreensão das relações raciais do Haiti. Para Gruner (2009, p.11),

"el artículo 14 (y toda la constitución a la cual pertenece) hace de facto la crítica, incluso anticipada, de una (ideo)lógica constitucional que imagina el Estadonación "moderno" como una unidad homogénea, sin distinciones de clases, "razas", género, etcétera. Al mismo tiempo (“al mismo tiempo") hay en la Constitución de 1805, y en el propio artículo 14, una concepción unitaria de la nación.”.

Seu esforço de reconstruir o país e fazer voltar ao seu antigo esplendor envolveu um conjunto de leis que obrigava a população a voltar às condições extremas de trabalho nas lavouras de açúcar, agora como "cultivadores". Aqueles que recusavam eram severamente punidos. O sonho da pequena propriedade, com produção em pequena escala para subsistência, era destruído quando chegava o inspetor de cultivo e antigo general da revolução, Jean-Jacques Dessalines. Com braço de ferro, Louverture controlava Saint Domingue e, ao mesmo tempo, reafirmava seu alinhamento com o governo francês através de várias cartas enviadas a Napoleão. 
No entanto, Napoleão não considerou essa lealdade de Louverture. Talvez influenciado por sua esposa Joséphine, filha de proprietários de lavouras em Martinica, Napoleão iniciou uma campanha para o retorno da escravidão nas colônias. Em 1801, enviou uma enorme tropa a Saint Domingue, liderada por seu cunhado Victoire Leclerc, que partiu acompanhado da irmã de Napoleão e dos dois filhos de Louverture a fim de conter a escalada de poder do governador geral. Foi a maior expedição enviada por Bonaparte a embates além da Europa: vinte mil soldados experientes primeiro, seguidos de outros vinte e três mil, dezoito meses depois.

Louverture, um astuto estrategista, usou seu conhecimento do clima e da geografia do país e iniciou uma guerra de guerrilha, que seria considerada tática de guerra na América Latina somente no século XX. (James, 1989). No entanto, aceitou conversar com um oficial francês sob a promessa de que estaria seguro. Neste momento foi capturado e deportado para o exílio em uma prisão na França. Lá, ao se recusar a revelar a Napoleão onde escondia suas supostas riquezas, foi isolado e colocado em condições pouco acolhedores, o que gerou sua morte pouco depois. (Dubois, 2004)

Grande parte dos súditos de Louverture, inclusive seu general Dessalines, passou para o lado francês logo no início da retomada do poder. Porém, as investidas em prol do retorno da escravidão, o desarmamento e execução das tropas de ex-escravos negros e outras medidas que indicavam o retorno à situação pré-revolução, levaram Dessalines, Christophe e outros generais que estavam lutando ao lado dos franceses a se revoltarem de novo ao mesmo tempo em que um surto de febre amarela assolava as tropas vindas da Europa. Em fins de 1802, a febre havia reduzido drasticamente o número de soldados e, enfim, matou Leclerc. Rochambeau, seu sucessor, iniciou um período de terror na ilha, com afogamentos em massa, enforcamentos, crucificação e fogueira para seus inimigos. Construiu uma arena em Cape Français para que cães dilacerassem negros diante de uma plateia formada por uma excitada elite de proprietários de lavouras. Para Rochambeau, somente o extermínio de todos os negros traria o esplendor da antiga colônia, que poderia facilmente voltar a trazer novos escravos da África. Este período de brutalidade durou até novembro de 1803, quando o que restou das tropas francesas ficaram cercadas, em terra pelos rebeldes negros, pelo mar pelos navios britânicos ${ }^{6}$. E assim, termina o período colonial de Saint Domingue, que passa a se chamar Haiti.

\footnotetext{
${ }^{6}$ A derrota no Haiti fez com que Napoleão desistisse de lutar pela Louisiana, na parte sul dos EUA.
} 
Metade da população havia morrido nos últimos treze anos de lutas, quando em primeiro de janeiro de 1804 foi proclamada a independência em uma série de celebrações em Gonaives. O trauma e o ódio aos franceses era tão grande que um dos oficiais presentes no momento da escritura da declaração da independência afirmou "devemos usar a pele de um homem branco como um pergaminho, seu crânio como tinteiro, seu sangue como tinta e uma baioneta como caneta". (apud Dubois, 2004, p.298)

Os EUA somente reconheceram a independência do Haiti em $1862^{7}$. Alguns nomes importantes da política norte-americana do século XIX, como George Fitzhugh e John Calhoun argumentavam que a escravidão era uma instituição humana capaz de manter o controle dos selvagens africanos. E completaram, se libertos eles iriam se chafurdar na preguiça e no caos.(Girard, 2010, p.61)

A maioria dos brancos de Saint Domingue que sobreviveram emigraram para os EUA, França ou para os países vizinhos. Notícias do levante negro espalharam o medo entre os proprietários de toda a região.

\section{O Novo Haiti}

Sob a liderança de Dessalines, o país tentava achar seu rumo, ainda baseado nas grandes monoculturas para exportação. Havia grande desconfiança com os poucos estrangeiros que ainda permaneciam no país e uma divisão racial interna, que colocava os mulatos como os mais ricos, mas mais discriminados. O maior legado de Dessalines foi a promulgação da primeira constituição do Haiti, com seu famoso artigo 14 que declarava que "Todos os cidadãos, de ora em diante, serão conhecidos pela denominação genérica de negros". A Constituição promulgada em 1805 foi escrita a partir dos rascunhos de Toussaint Louverture, feitos em 1801, que só pode se concretizar depois da independência do País. Segundo Gruner (2009, p.6)

\footnotetext{
Ningún otro texto da cuenta más elocuentemente de la naturaleza verdaderamente inaudita impensable e irrepresentable, para decirlo con Trouillot, de esa revolución. Ningún otro documento articula más claramente, en efecto, el carácter revolucionario del nuevo estado, la contra-modernidad sincrética de sus supuestos básicos subyacentes, y los asimismo

${ }^{7}$ A França só reconheceu a independência do Haiti mediante uma indenização. Em 1814 a França exigiu do Haiti uma indenização de 150 milhões de francos-ouro, que em 1838 rebaixou a 90 milhões. Foi só quando o Haiti aceitou a exigência que a França passou a reconhecê-lo como nação independente, recebendo as quotas da indenização que o Haiti terminou de pagar em 1883.
} 
extraordinarios desafíos que la revolución tuvo que enfrentar en el contexto de un segmento del sistema-mundo en el cual la esclavitud era regla, y donde la expansión colonialista estaba comenzando a extenderse hacia Asia y África, y el racialismo "taxonómico" empezaba a mutar hacia un aún más frontal racismo de base biológica y "científica".

O governo de Dessalines ${ }^{8}$ durou pouco. Em 1806 foi morto por um golpe de seus próprios generais. As divisões internas e disputas por poder marcaram as relações entre os exescravos e revolucionários desde seu início. Henri Christophe assumiu como presidente e Alexandre Pétion como presidente do senado, mas disputas entre os dois logo levaram a uma guerra civil. Christophe se declarou imperador do Haiti, mas controlava apenas o norte, enquanto Pétion governava o sul do país. Assim foi até que em 1818 morre Pétion e assume outro veterano da revolução, Jean-Pierre Boyer. Boyer reunifica o país depois da morte de Christophe em 1820. Durante seu governo, o sistema de grandes plantações de açúcar sustentadas por trabalho semi-escravo, voltado para a exportação, foi substituído por uma vasta divisão de terras, que passaram a representar uma economia voltada para a subsistência.

Durante muitos anos o Haiti foi lugar de destino de negros libertos dos EUA. Tanto os opositores quanto os apoiadores da escravidão nos EUA simpatizavam com a ideia dos negros emigrarem para a África, principalmente depois da fundação da Libéria em 1817, ou para o Haiti. O Haiti era mais próximo e mais viável era a viagem para lá. A emigração no período da presidência de Boyer chegou a quatro mil negros norte-americanos e continuou a crescer até a criação em 1860 do Haytian Bureau of Emigration in the United States. Embalados por ideias como a de Abraham Lincoln, que acreditava que a melhor solução para os negros libertos no país era a deportação em massa a fim de equilibrar liberdade com harmonia social, o governo dos EUA criou um fundo em 1862 onde um quarto das vendas de propriedades no sul seriam depositados para financiar a emigração dos negros. O Haiti era o principal destino. (Fanning, 2015) O governo de Faustin Soulouque, de 1849 a 1859, foi marcado por um discurso de nacionalismo racialista forte. Depois de dois governantes mulatos, Pétion e Boyer, Soulouque se orgulhava de sua pele negra e fez mudanças importantes na configuração de poder dentro do Haiti com base na raça. Muito antes de Jean Price-Mars, Aimée Cesaire e Walter Rodney, Soulouque já pregava o orgulho negro e a independência intelectual dos haitianos. Foi, por exemplo, o primeiro presidente a assumir sua filiação ao vodu. Esse orgulho contrastava com os ataques que recebia da mídia internacional. Nenhuma outra figura

\footnotetext{
${ }^{8}$ Ao saber que Napoléão iria ser coroado imperador, Dessalines preparou sua própria cerimônia de coroação e passou a ser denominado Jacques I, imperador do Haiti.
} 
pública no Haiti havia sido tão ridicularizada por jornalistas e caricaturistas. Nos jornais europeus e nas caricaturas de Cham e Honoré Daumier, por exemplo, Soulouque aparecia vestido de trajes ultrajantes e com aparência de símios africanos.(Childs, 2004)

O período pós-independência foi marcado por longos períodos de governo ditatoriais (Christophe, 14 anos, Boyer 25 anos, Soulouque 12 anos), golpes, guerras civis e muitos distúrbios econômicos que culminaram na invasão das forças norte-americanas em 1915.

Em março de 1915 assumiu a presidência do Haiti Jean Vilbrun Guillaume Sam, em um período de grande turbulência política. Quando inicia 1914 o Haiti já havia tido três diferentes presidentes. Sua ascendência ao poder se deu principalmente pela força de sua milícia privada, chamada Cacos.

Receoso de que um novo golpe o tirasse do poder, prendeu e fez de reféns cerca de duzentos membros das mais ricas e prestigiosas famílias do Haiti e deu ordem a seus guardas de que se algo acontecesse a ele, estes reféns deveriam ser executados. Não tardou quatro meses e Sam foi atacado em seu palácio presidencial, conseguindo fugir para a embaixada da França. Cientes da tentativa de golpe, os guardas esquartejaram os reféns na prisão, que ficaram irreconhecíveis depois da chacina. Uma multidão enfurecida invadiu a embaixada e encontraram Guillaume Sam escondido no banheiro da residência do embaixador. Arrastaram o presidente aos chutes e socos até a rua, onde foi morto por linchamento. Sob o pretexto da violação da embaixada da França, diplomatas estrangeiros alegaram a necessidade de intervenção externa diante de um Haiti ingovernável. Não demorou muito, tropas norteamericanas invadiram a capital e assumiram o controle do país. Depois de 111 anos de independência, o Haiti retornava a sua condição de colônia.

As milícias foram desarmadas, os marines norte-americanos tomaram todas as regiões do país e membros da elite política foram enviados ao exílio. Os EUA tinham o monopólio da violência, reforçados por uma lei marcial severa. O controle se estendia à alfândega e ao banco nacional, tudo era administrado segundo as ordens da Casa Branca. O presidente continuava sendo um haitiano, mas os EUA designavam os dirigentes dos cinco principais setores do governo: forças armadas, alfândega, finanças, saúde pública e infraestrutura. Ainda que o congresso tenha sido mantido, o pagamento dos salários era adiado caso resistissem às decisões norte-americanas.

Em 1916, a Lei de Corvée de 1863 foi ressuscitada e previa que todos deveriam ajudar na construção de estradas, com trabalho ou com pagamento. Como a maioria da população era 
pobre, foram obrigados a servir nas frentes de trabalho duro nas estradas. Muitos eram obrigados violentamente pelos soldados norte-americanos, que não tinham temor em mantêlos amarrados enquanto trabalhavam. A memória do tempo de escravidão ajudava a criar maior tensão no país. Os anos de domínio dos EUA foram marcados por ações violentas, racismo e abuso de poder. Logo se iniciou uma guerra de guerrilha, liderada no lado haitiano por Charles Péralte.

Várias acusações de abuso das forças norte-americanas eram publicadas nos jornais nacionais e repercutiam internacionalmente. Alguns oficiais foram retirados do Haiti sob provas de escravizar e executar moradores e prisioneiros. (Dalleo, 2016). Em 1920, a milícia liderada por Péralte foi brutalmente dizimada, acabando com a resistência mais organizada à invasão norte-americana. Soldados norte-americanos foram autorizados a destruir templos vodus, criando ainda mais tensão no país. O governo dos EUA pregava democracia para o Haiti enquanto praticava ocupação e racismo, numa incoerente combinação. Depois de árduas negociações, os EUA retiraram suas tropas em agosto de 1934, deixando um rastro de ressentimento e xenofobismo.

Em 1937, mais um massacre de fundo racial marcou a história do Haiti. Mais de quinze mil haitianos que trabalhavam na vizinha República Dominicana foram brutalmente assassinados por ordem do ditador Rafael Trujillo. A ordem era matar qualquer negro na região, gerando a morte de muitos dominicanos de descendência haitiana. O presidente haitiano, Sténio Vincent, mulato, pouco se manifestou neste incidente tão trágico. Depois de negociar uma insuficiente indenização por parte do governo dominicano, deu por encerrada a questão ${ }^{9}$.

Depois de mais um período de turbulência política, em 1957, o Haiti foi às urnas para eleger seu próximo presidente. Um dos dois principais candidatos era um mulato chamado Louis Déjoie que não escondia seu racismo, chegando a afirmar que, se eleito, destruiria o

\footnotetext{
${ }^{9}$ Em outubro de 1937, Rafael Trujillo ordenou o massacre de cerca de 15.000 haitianos que viviam na República Dominicana, pelo simples motivo de serem haitianos ${ }^{3}$. O ataque veio como uma surpresa completa para estes haitianos, bem como para muitos dominicanos, e atingiu mulheres, homens e crianças indiscriminadamente. Nenhum evento prévio os havia advertido do que estava prestes a acontecer. Trujillo ordenou que seus soldados usassem facões em vez de armas, uma brutalidade expressa pelo nome que se deu em espanhol, El Corte. Aqueles que sobreviveram viveram com lesões permanentes, cicatrizes e deficiências, bem como o trauma psicológico de ter sobrevivido a um genocídio. O massacre era parte do programa de Trujillo de dominicanização da fronteira, onde se concentravam muitos haitianos e dominicanos descendentes de haitianos, permitindo uma maior mestiçagem racial, cultural e religiosa. Cabe lembrar que o massacre ocorre em um momento em que a Europa vivia a ideologia da purificação racial por meio do fascismo na Espanha e a ascensão de Hitler na Alemanha.
} 
exército e enviaria todos os negros de volta para o lugar onde pertenciam, os campos. O outro, François Duvalier, era um médico negro que havia passado anos cuidando de doenças tropicais no interior do país. Duvalier vence as eleições com uma boa vantagem, garantida pelo voto da população negra do interior.

Duvalier foi profundamente influenciado pelo movimento noiriste ${ }^{10}$ iniciado por Jean Price-Mars, que evocava o orgulho de ser negro e das origens africanas na população haitiana, reforçado pelas lembranças da ocupação norte-americana. A exaltação de um nacionalismo negro e o anti-americanismo fizeram parte da sua retórica durante todo seu governo. Seu trabalho como médico lhe rendeu o apelido de Papa Doc. O que ninguém imaginou era como seria seu governo, marcado por prisões, execuções em massa e estupros coletivos. Uma das ditaduras mais violentas da América Latina. Nada antes seria comparável ao período de terror iniciado por este tímido e discreto médico haitiano. Qualquer opositor era morto brutalmente, juntamente com suas esposas e maridos, filhos, pais, avós e amigos. Papa Doc perseguiu profissionais com bom nível de educação, estudantes e outros membros da elite do país, temendo a propagação de ideais democráticos. Essa camada mais educada da população emigrou em massa, deixando o país sem médicos ou cirurgiões ${ }^{11}$. Em 1969, ele fechou o Office National d'Alphabétisation et d'Action Communautaire, órgão responsável por programas de alfebetização no país, preferindo governar uma população pobre e analfabeta para evitar uma oposição qualificada. O que fez Papa Doc se transformar de um benevolente médico do interior a um dos mais violentos tiranos do século XX é um mistério. Para executar seus desígnios, ele tinha um contingente de leais soldados chamados de Tontons Macoutes, recrutados da camada mais baixa de negros do Haiti e formada tanto de homens como de mulheres.

Após sua morte, como previsto, assumiu seu filho de dezoito anos de idade. Bébé (Baby) doc, como era chamado, não parecia capaz de continuar o reinado de terror do pai. No entanto, Jean-Claude Duvalier manteve a mesma estrutura repressiva do pai, os Tontons

\footnotetext{
${ }^{10} \mathrm{O}$ noirisme deve ser entendida como uma ideologia radical, psicológica, cultural, etnológica e políticamente, que defendeu a supremacia negra na política haitiana. Enquanto alguns consideram o noirisme uma forma de Négritude do Haiti, Michael Dash (2011) avalia que a maioria dos escritores da Négritude (Aimé Cesaire, Leopold Sedar Senghor etc) se distanciaram do noirismo quando perceberam a extensão do seu radicalismo.

${ }^{11}$ Segundo Cédric Audebert, "a autoproclamação de "Presidente vitalício" de François Duvalier em 1964 assustou os intelectuais e a classe média negra (médicos, advogados, professores) que não demoraram para ir ao exílio. Entre 1957 - o ano de ascensão de Duvalier ao poder - e 1963, 6.800 haitianos foram para os Estados Unidos com visto de imigrantes e outros 27.300 com visto temporário. Entre o ano da autoproclamação em 1964 até o ano da sua morte em 1971, os serviços de imigração estadunidense registraram 40.100 imigrantes e 100.000 não -imigrantes oriundos do Haiti (Audebert, 2012, p. 26-27).
} 
Macoutes e as câmaras de tortura, porém, com uma aparência externa mais agradável aos olhos estrangeiros. Dessa forma, a ajuda internacional aumentou exponencialmente (a ajuda dos EUA passou de 3.8 milhões a 35.5 milhões). Na década de setenta, o orçamento do país era formado por 70 por cento de ajuda internacional e o desvio de dinheiro para cofres particulares e a corrupção eram imensos. Segundo Girard (2010, p. 106), Baby Doc descobriu que a pobreza era sua principal fonte de riqueza e, dessa forma, deixava crianças passarem fome para aumentar a ajuda internacional. Foi neste momento que a chegada das ONGs estrangeiras foi impulsionada a números extraordinários, gerando uma dependência ainda maior em relação à comunidade internacional. Receosos da corrupção do governo haitiano, a ajuda externa chegava através das ONGs que, muitas vezes, estabeleciam uma relação duvidosa com o Estado. Em 1984, a Haitian American Voluntary Association estimava que cerca de 300 ONGs trabalhavam no país, dez anos mais tarde esse número sobe para cerca de 800 e, em 2010, no momento do terremoto, esse número era estimado em dez mil organizações. (Pierre-Louis, 2011, p.190)

Trabalhadores de lavouras de cana de açúcar haitianos eram enviados à República Dominicana pelo valor de $\$ 50$ dólares a pessoa, mais do que o pagamento pelos mortos no massacre de 1937. Esse lucrativo comércio de trabalhadores, colocava centenas de haitianos em condições muito semelhantes à escravidão colonial. O turismo na capital atraia estrangeiros do mundo todo, ansiosos pelas promessas de satisfazer qualquer fantasia sexual com crianças famintas que aceitavam qualquer coisa em troca de poucos gourdes. O êxodo do campo para a cidade fez nascer grandes favelas na capital, como La Saline e Cité Soleil e aumentar o número de desabrigados nas ruas. Todo esse cenário gerou um forte movimento migratório cujos destinos principais eram Miami, Nova York, Montreal e Paris. Diferente da emigração causada pelo período de repressão durante o governo de Papa Doc, em que a maioria era formada de pessoas de classe média e classe alta, agora era formada por um contingente de pessoas fugindo da extrema pobreza iniciando a maior diáspora haitiana até então.

Com Baby Doc começou o fluxo das chamadas boat people que cruzavam o mar do caribe em embarcações pouco melhores que jangadas. O fenômeno do boat people teve seu auge de 1977 a 1981 quando 50.000 a 70.000 haitianos chegaram vivos às costas da Flórida, tendo morrido muitos nesse mesmo período em alto mar. (Handerson, 2015). As embarcações eram frágeis e superlotadas, sendo muitas vezes incapazes tecnicamente de chegar à costa 
norte-americana. As que conseguiam eram interceptadas ou mesmo afundadas pela intervenção da guarda costeira.

Em setembro de 1981, diante do imenso fluxo de haitianos chegando à costa dos EUA, Baby Doc assina um acordo com a administração Reagan permitindo que a guarda costeira norte-americana patrulhasse o litoral do Haiti para interceptar a saída dos potenciais refugiados. A onda de refugiados arrefeceu para recomeçar somente durante a crise econômica e política dos anos noventa. O enorme impacto e propagação da AIDS no Haiti, no final dos anos 70, contribuiu para maior rejeição aos migrantes vindos do Haiti para qualquer destinação. Já tinham o estereotipo de famintos, adoradores do diabo e agora aidéticos perigosos em uma época de muito medo e desinformação.

Depois de várias crises econômicas e políticas, pressionado pelas forças internacionais, em 1986, quinze anos depois de assumir o governo, Baby Doc foge do país em um avião providenciado pelos EUA junto com sua família e todo o luxo que conseguiram carregar, deixando para trás um país extremamente espoliado por anos de duvalierismo. Só retorna ao país em 2011, onde morreu três anos depois. Quando ele deixou o governo em 1986, o número de refugiados haitianos chegava a um milhão. O que se seguiu foi uma série de governos $\operatorname{curtos}^{12}$ e instáveis, não promovendo qualquer alteração substancial na vida da população.

\section{A emergência de Jean-Bertrand Aristide}

Em 1988 ganha destaque um jovem padre chamado Jean Bertrand Aristide que pregava na periferia pobre de Porto Príncipe. Um homem negro de origem rural chamava a atenção pela coragem política e pela oratória. Pregava regularmente na rádio local contra o duvalierismo, especialmente durante o governo de Baby doc. Durante uma missa em 11 de setembro de 1988, com a igreja repleta com cerca de oitocentos membros, Aristide foi interrompido em seu sermão por homens armados com armas e facões que massacraram os fiéis sem piedade, deixando um cenário de mortos e mutilados. Treze morreram e muitos ficaram feridos. Após o ataque, incendiaram a igreja e fugiram. De alguma forma, Aristide sobreviveu e a ferocidade da caçada dos Macoutes demonstrou o quanto seus sermões estavam incomodando. Este horrível evento marcou a ascensão política de Aristide, um padre

\footnotetext{
12 Conselho Nacional de Governo (de 7/2/1986 a 7/2/1988), Leslie Manigat (7/2/1988 a 20/6/1988), Henri Namphy (21/6/1988 a 17/9/1988), Prosper Avril (17/9/1988 a 10/3/1990), Hérard Abraham (10 a 13/3/1990), Ertha Pascal Trouillot (13/3/1990 a 7/2/1991).
} 
salesiano que havia estudado no exterior, especialmente em Israel, Grécia e Canadá, com mestrado em psicologia e doutorado em teologia. Em 1990, Aristide lança sua candidatura à presidência, competindo contra Roger Lafontant, antigo ministro do interior de Baby Doc.

Em dezembro de 1990 o Haiti viveu um evento pouco usual, uma eleição democrática quase pacífica. Longas filas de pessoas cheias de esperança garantiram a maioria dos votos de Aristide. No entanto, em setembro de 1991, após chegar de uma viagem presidencial à Nova Iorque, Aristide foi avisado de que um golpe de estado estava em andamento. Da bela praça em frente ao palácio presidencial, Aristide fez um duro discurso contra o golpe, ao lado do principal suspeito, o comandante das forças armadas Raoul Cédras, que lhe assegurou que nenhuma conspiração havia. No dia 29, Aristide foi capturado e enviado ao exílio em Caracas em um avião norte-americano pelo líder do golpe, Raoul Cédras. Nas semanas seguintes centenas de homens e mulheres foram mortos pela repressão política. Os mais pobres, principais apoiadores de Aristide, tornaram-se os mais perseguidos pelo brutal regime de Cédras. Corpos desfigurados e mutilados eram frequentemente jogados nas ruas como forma de intimidação a qualquer oposição. Essa combinação de pobreza e perseguição violenta, levou a maior onda de emigração do Haiti. Para cerca de trezentos mil haitianos a única opção era se arriscar nas frágeis embarcações que partiam para a Flórida.

Iniciou-se a partir deste momento a maior onda de migração haitiana, a maioria chamada de boat people para os EUA. Essa onda durou de 1991 a 1994, bloqueada pelas imensas dificuldades, especialmente as altas ondas e tempestades que regularmente afundavam pequenas embarcações repletas de futuros refugiados ou o policiamento frequente da Guarda Costeira Norte-Americana, que encaminhava os haitianos para Guantánamo. Apesar da evasão de milhares de haitianos, somente 54 foram legalizados como refugiados nos EUA em 1992, comparado com 3720 cubanos no mesmo ano. Segundo Wooding e Moseley-Williams (2009), mais de 100.000 haitianos deixaram o país em 1991, não só em direção aos EUA, mas também para as vizinhas Cuba e República Dominicana.

As mulheres foram especialmente atingidas, uma vez que constituíam uma base forte do governo Aristide. No relatório da Comissão nacional de verdade e justiça do Haiti, verificou-se a prática de centenas de estupros como forma de repressão, fora aqueles que não foram relatados pelo constrangimento social que passavam as mulheres. Muitos ocorreram por gangues de estupradores e na frente dos familiares. Sua execução era muitas vezes 
seguida do aviso de que era o preço por apoiar Aristide. Há relatos de crianças de até um ano de idade entre as vítimas.

Sob o acordo de repatriação do período Reagan-Duvalier, 23 mil haitianos em balsas e embarcações foram interceptados de 1981 a 1991. Desses, apenas 28 foram recebidos nos EUA. Ainda assim, o Governo Bush tomou providências para endurecer a política de repatriação. Ao invés de repatriá-los, o que causava um alvoroço jurídico no país, enviava-os para Guantánamo em condições muito precárias. Logo a base estava repleta com nove mil haitianos. Em maio de 1992, uma nova decisão alegava que os desejosos de ir para os EUA deveriam pleitear a condição de perseguidos políticos ainda no Haiti, sob os olhares daqueles de quem queriam fugir. Caso não o fizessem antecipadamente seriam imediatamente repatriados sem direito a ter seu pleito analisado na justiça norteamericana.

Nos EUA a comunidade haitiana já somava milhões, principalmente vindos do período Duvalier. Outro milhão havia emigrado para República Dominicana, Canadá, França, Cuba, Venezuela e Bahamas. Os haitianos de classe média e alta, educados, que fugiram de Papa Doc, configuravam um perfil diferente de haitianos, não muito receptivos aos novos chegados. Além da falta de receptividade de seus compatriotas, havia uma enorme desconfiança local que gerava dificuldades para alugar apartamentos, muito devido aos rumores de que haitianos, adoradores do diabo, tocavam seus tambores aos deuses vodus por toda a noite.

Em 1993, o governo Clinton teve um papel proeminente no Conselho de Segurança da ONU para a decisão de enviar observadores ao Haiti e para cessar a ajuda da Organização. Cédras, que parecia não se importar com os impactos dos embargos sobre a maioria da população, sentiu-se atingido pelo fim da ajuda humanitária da ONU. Em duas semanas se propôs a ir a Nova Iorque negociar com o governo deposto. Do acordo resultou a previsão de volta de Aristide à presidência em outubro do mesmo ano e anistia para os crimes de Cédras, em troca também da retomada da ajuda externa. Tão logo a ajuda internacional reiniciou, recomeçaram também os ataques violentos do regime. Os aliados de Aristide que sobraram foram rapidamente mortos, a despeito dos observadores da ONU. Era um recado claro de que não havia disposição em cumprir o acordo. Em lugar dos terríveis Macoutes da era duvalier, surgiu a FRAPH, Front Révolutionnaire Armé pour le Progrés d'Haiti. Sua principal meta era sequestrar, torturar e matar aliados de Aristide. 
A despeito do cenário pouco auspicioso, o navio norte-americano Harlan County foi enviado com tropas para operacionalizar a transição e a chegada de Aristide. A recepção das tropas americanas foi bastante hostil, impedindo seu desembarque com ameaças de conflito. Depois de muitos debates na Casa Branca, o navio retornou sem enfrentar Cédras e seus aliados armados ostensivamente com facões e armas de fogo. O desenrolar político da debandada norte-americana fez com que novamente se preparassem para uma invasão ao Haiti.

Em 1994, havia um forte movimento em prol da invasão norte-americana, apoiada secretamente por Aristide e seus aliados. Paralelamente, o número de emigrantes aumentava. Para ganhar maior legitimidade, Clinton pede apoio às Nações Unidas para uma intervenção no Haiti. Em julho de 1994, a Resolução 940 do Conselho de Segurança autorizava o uso da força para restaurar Aristide no poder. A diáspora haitiana, especialmente nos EUA teve um papel importante no retorno do Aristide para Haiti, os haitianos residentes nos EUA pressionavam o Governo americano para intervir nos assuntos políticos do Haiti e levar o Aristide de volta ao Governo haitiano. O acordo para ajuda financeira especificava que o recurso seria administrado por ONGs ao invés do governo haitiano para evitar desvio de recursos, aumentando o fluxo de organismos internacionais para a região. Em setembro uma imensa força norteamericana de vinte mil homens chegou ao Haiti preparada para a guerra. No entanto, uma tentativa de negociação de última hora entre Jimmy Carter, Colin Powell e Sam Nunn com a junta que governava o Haiti sob a liderança de Cédras evitou o embate. Retiraram-se as tropas de guerra e retornaram as forças de paz, sob o codinome de Operação Restauração da Democracia.

Cédras partiu para o exílio no Panamá e Aristide reassumiu em outubro de 1994, um país ainda mais castigado pela violência, pela pobreza e pela emigração em massa. Antes do fim de 1995, Aristide já havia enfrentado duas tentativas de golpe para tirá-lo do poder e dependia fortemente do apoio externo para reconstruir o país. Apesar de todas as dificuldades, Aristide chegou ao fim do mandato com uma nova eleição que levou à presidência René Préval, ministro de Aristide e seu principal aliado. Durante o governo de Préval houve um rompimento político entre os dois antigos aliados, levando a uma divisão interna no partido Lavalas. Toda essa crise política também teve impactos econômicos. Em 2001, em uma polêmica eleição Aristide volta ao poder. 
No terceiro mandato de Aristide duas coisas chamam a atenção: seu pedido para o envio de novas forças da $\mathrm{ONu}$, a despeito de seu discurso de extremo nacionalismo, e a presença de figuras importantes do Duvalierismo em seu círculo político mais próximo. Esse novo governo ficou muito aquém do prometido em seus discursos, elevando o Haiti ao primeiro lugar entre os países considerados mais corruptos do mundo, no ranking da Transparência Internacional, além de seu histórico título de mais pobre do hemisfério ocidental. Outro ranking chama a atenção, o topo da lista dos países envolvidos com o narcotráfico, já que era uma rota necessária para os carregamentos indo da América do Sul para a Flórida. O envolvimento com o mercado de drogas mundial era sentido em toda a sociedade, inclusive entre os políticos do alto escalão de Aristide ${ }^{13}$. Uma nova milícia violenta ligada ao governo surgiu nos moldes dos antigos Macoutes ou FRAPH - a Chimèra responsável por dezenas de assassinatos políticos.

A oposição política crescia assim como diminuía o apoio internacional. Em 2004, uma nova ameaça de golpe parecia verossímil. Os rebeldes, encabeçados pela Frente de Revolução Nacional para libertação do Haiti, estavam avançando rapidamente. Sem o suporte dos EUA ou da França para enfrentar esta nova ameaça, Aristide deixa o Haiti e parte para o exílio mais uma vez em 29 de fevereiro de 2004. O país mergulhou em mais uma crise política, sem uma liderança clara na presidência, e deixado na mão de "chefs de guerre" locais. No ano de comemoração do bicentenário da independência, o Haiti enfrentava uma grave crise de governabilidade.

Para agravar a crise sócio-econômica que se instaurara, no mesmo ano, o furacão Jeanne que atingiu a costa norte do país deixou cerca de três mil haitianos mortos, mil desaparecidos e trezentos mil desabrigados. Gonaives ficou destruída. O mesmo furacão havia deixado nove mortos nas Bahamas, sete na República Dominicana e dois em Porto Rico, mas no Haiti, as condições geográficas locais agravaram o impacto e as condições políticas fizerem com que o socorro fosse débil. O primeiro caminhão com suprimentos de comida e medicamentos foi enviado pelo World Food Program, antes mesmo de qualquer socorro vindo do governo haitiano. Infelizmente sua carga foi saqueada e vendida a preços inacessíveis às vítimas.

\footnotetext{
${ }^{13}$ Aristide foi acusado de forte envolvimento com o narcotráfico internacional, que gerou uma grande parte de sua fortuna pessoal.
} 
Após vários problemas, sob os auspícios da MINUSTAH ${ }^{14}$, ocorreram eleições em fevereiro de 2006. Depois de dois anos sem presidente, o Haiti elegeu em uma polémica eleição, René Préval novamente. Durante seu governo, o Haiti enfrentou um de seus maiores desafios, o terremoto. $\mathrm{O}$ ano de 2010 tem sido considerado o mais terrível da história haitiana, que se inicia com o terremoto de 7.0 de 12 de janeiro que destruiu a região metropolitana de Porto Príncipe, matando 316 mil pessoas e deixando um milhão e meio de desabrigados. No mesmo ano, começa o maior surto de cólera provocado pela contaminação com soldados nepaleses, matando oito mil pessoas e infectando mais de oitocentos mil. A partir dessa série de eventos trágicos, 350 mil haitianos deixam o país.

De acordo com o geógrafo, político e novelista haitiano Georges Anglade, os haitianos na diáspora constituem o Dixième Département, como uma província do país formada pela massa de migrantes que mantém seu vínculo afetivo, cultural e econômico com sua terra natal. Este panorama histórico nos revela que grande parte desses migrantes foram "expulsos" pelas circunstâncias adversas no país.

Há a prevalência de cinco ondas principais de emigração, ainda que este movimento para fora sempre esteve presente desde o período colonial, com a ida de filhos da classe média e alta para as escolas e universidades no exterior. Este movimento migratório cresce no período da ocupação norte-americana de 1915 a 1943, que provoca a mobilidade de trabalhadores para as indústrias americanas de cana-de-açúcar, especialmente para Cuba e para a República Dominicana. Este movimento de trabalhadores, muitos deles sazonais, ocasionou a ida de cerca de quarenta mil haitianos por ano para os campos de cana-de-açúcar nos países vizinhos. A forte presença de haitianos trabalhando nas regiões rurais da República Dominicana foi ofuscada pelo massacre de 1937, ocorrido na fronteira do país.

Mas a escala e dimensão do processo migratório começou a subir de nível a partir do governo de Papa Doc. A repressão promovida pelos Tontons Macoutes a serviço do governo, voltada principalmente para uma classe mais educada de profissionais liberais, médicos, advogados, professores, especialmente mulatos, gerou uma onda migratória com um perfil bastante definido. A fuga de pessoas com este perfil já havia sido sentida quando os religiosos estrangeiros que cuidavam do sistema educacional do Haiti deixaram o país no período da Revolução Haitiana, gerando a primeira "fuga de cérebros". A falta de apoio estrangeiro e o

\footnotetext{
${ }^{14}$ Em 1995 o Haiti aboliu as Forças Armadas e sua segurança ficou a cargo de uma Polícia Nacional. De 1993 a 2013 sete missões de intervenção militar, policial e civil patrocinadas pela ONU foram enviadas ao país.
} 
xenofobismo interno fez com que a expertise em algumas áreas demorasse a surgir após a independência do país em 1804. Mas, o verdadeiro vácuo de profissionais capacitados foi sentida no primeiro governo Duvalier.

Uma segunda onda está identificada com uma exacerbação da pobreza e das fragilidades econômicas sentidas durante o governo de Baby Doc, de 1977 a 1981. Esse perfil de migrantes é muito diferente da primeira onda, já que é representado pela camada mais pobre da população fugindo da falta de oportunidade local. Começam a surgir os balseiros ou "boat people", que tentam alcançar a costa dos EUA.

A crise humanitária gerada pela precariedade dos "boat people" vai arrefecer nos anos oitenta para ressurgir com maior força nos anos noventa. Com a absoluta crueldade do governo de Raoul Cédras, que identifica (corretamente) os apoiadores de seu oponente, o presidente deposto Jean Bertrand Aristide, entre a população mais pobre, principalmente entre os negros habitantes das favelas, reinicia a fuga de haitianos, principalmente por meio das frágeis embarcações disponíveis. As medidas restritivas impostas pelo governo norteamericano à entrada de migrantes haitianos e o retorno de Aristide fazem reduzir este fluxo na segunda metade da década de noventa.

Por fim, a onda migratória chega a seu ápice depois do terremoto de janeiro de 2010, ocasionando uma das maiores crises vividas pelo já sofrido país. Para muitos, não havia outra opção senão emigrar. O Brasil entra no cenário como um dos países de destino mais procurados e tem que lidar com uma nova realidade internacional e local.

\begin{tabular}{|l|l|ll|}
\hline \multicolumn{4}{|c|}{ PRINCIPAIS ONDAS EMIGRATÓRIAS } \\
\hline PERÍODO & PERFIL & \multicolumn{2}{l|}{ Principais Destinos } \\
\hline $\begin{array}{l}1915 \text { a } 1943 \text { - Ocupação } \\
\text { dos EUA }\end{array}$ & $\begin{array}{l}\text { Trabalhadores para as } \\
\text { lavouras de cana-de-açucar } \\
\text { de propriedade dos EUA }\end{array}$ & $\begin{array}{l}\text { Cuba e República } \\
\text { Dominicana }\end{array}$ \\
\hline $\begin{array}{l}1957 \text { a 1971 - Ditadura de } \\
\text { Papa Doc }\end{array}$ & $\begin{array}{l}\text { Classe média educada e } \\
\text { profissionais, a maioria } \\
\text { mulatos, em fuga da } \\
\text { repressão. }\end{array}$ & $\begin{array}{l}\text { EUA, Canadá, Bahamas, } \\
\text { africanos alguns países } \\
\text { francesa. de língua }\end{array}$ \\
\hline 1977 a 1981 - Ditadura de & $\begin{array}{l}\text { Classe pobre em fuga das } \\
\text { condições econômicas }\end{array}$ & EUA e França \\
\hline
\end{tabular}




\begin{tabular}{|l|l|lll|}
\hline Baby Doc & $\begin{array}{l}\text { adversas. Inicio do } \\
\text { fenômeno dos boat people. }\end{array}$ & & & \\
\hline 1991 a 1994 - Ditadura de & $\begin{array}{l}\text { Classe mais pobre, maioria } \\
\text { negros, fugindo da } \\
\text { repressão política }\end{array}$ & $\begin{array}{l}\text { EUA e República } \\
\text { Dominicana. }\end{array}$ & \\
\hline Terremoto de 2010 & $\begin{array}{l}\text { Perfil diverso, fugindo das } \\
\text { condições adras adversas } \\
\text { exacerbadas pelo terremoto } \\
\text { e seus desdobramentos. }\end{array}$ & Erancesa & e Guiana \\
\hline
\end{tabular}

\section{Breves Considerações Finais}

Muito fatores afetam o desenrolar sócio-histórico de um país. Em tempos de globalização, de lutas engendradas numa cruel geopolítica que mantém países em situação hegemônica e outros em reiterada subordinação, não há como isolar fatores internos de fatores regionais e globais. Principalmente quando tratamos do Caribe, considerado fronteira imperial de várias potências, os usos e abusos da política internacional é evidente.

Apesar de consciente disso, este artigo não se centrou nesta articulação global de forças internas e externas. Procurou trazer à tona os diversos momentos históricos que marcaram esse tão importante país para lançar luz na temática da emigração a partir de um aspecto limitado, mas importante: a política interna.

Desde que foi considerado a "pérola" entre as colônias até o rótulo de país mais pobre da América Latina, o Haiti é objeto de profundo desconhecimento, mitificação e interpretações equivocadas. No Brasil, especialmente, o país começa a ganha interesse a partir da chegada de grande quantidade de migrantes, especialmente a partir da segunda década do Século XXI. Ainda assim, uma bruma de desconhecimento paira sobre a rica história do Haiti. Este artigo é um convite a que se valorize esse país como exemplo de luta de um povo contra a dominação e a favor da valorização de sua cultura e história.

\section{Bibliografia}

ABBOT, Elizabeth. Haiti: A Shattered Nation. Duckworth Overlook, 2011. 
HANDERSON, Joseph. Diáspora. As dinâmicas da mobilidade haitiana no Brasil, no Suriname e na Guiana Francesa. Universidade Federal do Rio de Janeiro, 2015.

HURBON, Laennec. O Deus da resistência negra: o vodu haitiano. Edições Paulinas, 1972.

ANGLADE, Georges. L'espace haïtien. Les Presses de l'Université du Québec, 1975.

CHILDS, Elizabeth. Daumier and Exoticism: Satirizing the French and the Foreign. Peter Langing Publishing, 2004.

DALLEO, Raphael. American imperialism's undead: the Occupation of Haiti and the rise of caribbean anticolonialism. University of Virgina Press, 2016

DUBOIS, Laurent e GARRIGUS, John, Slave Revolution in the Caribbean, 1789-1804: a brief history with documents, New York: Bedford/St Martin, 2006.

DUBOIS, Laurent. Avengers of the New World: the Story of the Haitian Revolution, Cambridge, Harvard University Press, 2004.

DUBOIS, Laurent. Haiti: The Aftershocks of History. Metropolitan Books,2012.

FANNING, Sara. Caribbean Crossing: African Americans and the Haitian Emigration Movement. New York University Press, 2015)

GIRARD, Philippe. Haiti: The Tumultuous History - From Pearl of the Caribbean to Broken Nation. St. Martin's Press,2010.

GROS, Jean-Germain. Anatomy of a Haitian Tragedy: When the Fury of Nature Meets the Debility of the State. Journal of Black Studies, Vol. 42, No. 2, 2011

GRÜNER, Eduardo: Haití: "Una (olvidada) revolución filosófica” en Revista SOCIEDAD No 28, Prometeo, Buenos Aires, 2009.

ICART, Jean-Claude. La migration haitienne dans le monde. Entre gens de bateau, apatrides et migrants environnementaux. Revue Haitiano-Caraibéenne, volume 6, n.1, Mai 2017.

JAMES, C.L.R. The Black Jacobins: Toussaint L'Ouverture and the San Domingo Revolution. Vintage Books, 1989.

MIDY, Franklin. Transition démocratique em Haiti! Mais démocratie dans quel État?. Revue Haitiano-Caraibéenne, volume 6, n.1, Mai 2017.

PIERRE-LOUIS, François. Earthquakes, Nongovernmental Organizations, and Governance in Haiti. Journal of Black Studies, Vol. 42, No. 2, 2011

REINHARDT, Thomas. 200 Years of Forgetting: Hushing up the Haitian Revolution. Journal of Black Studies, Vol. 35, No. 4 (Mar., 2005), pp. 246-261

SEITENFUS, Ricardo. Haiti: dilemas e fracassos internacionais. UniJui, 2014. 
TROUILLOT, Michel-Rolph. Silencing the Past: Power and the Production of History. Boston: Beacon Press, 1995.

WOODING, Bridget, MOSELEY, Richard. Necessaires, mas indésirables: les immigrants haitiens et leurs descendants en République Dominicaine. Port au Prince: Editions de l’University d'Etat, 2009.

\title{
Haiti: Aspectos Socio-Históricos Internos e Emigração
}

\section{Resumo}

O Haiti, um Estado fundado constitucionalmente na igualdade entre negros e brancos, vive no cotidiano uma cruel divisão racial entre negros e mulatos, uma complexa relação com os estrangeiros e, apesar da imensa riqueza geográfica e cultural, fraqueza e corrupção institucional paralisam seu desenvolvimento. Este texto se propõe a uma breve análise sócio-histórica, explanada de forma cronológica e linear para facilitar o encadeamento dos eventos, a fim de dar subsídios para a compreensão de alguns desses paradoxos e dos motivos do grande número de haitianos que emigram deste país.

Palavra-Chaves: Haiti. Migração. Revolução Haitiana

\section{Haiti: Internal Socio-Historical Aspects and Emigration}

\begin{abstract}
Haiti, a state constitutionally founded in equality between blacks and whites, lives in daily life a cruel racial division between blacks and mulattoes, a complex relationship with foreigners, and despite immense geographic and cultural wealth, the institutional weakness and corruption paralyze its development. This text proposes a brief socio-historical analysis, chronologically and linearly explained to facilitate the chain of events, in order to provide support for the understanding of some of these paradoxes and the reasons for the large number of Haitians emigrating from this country.
\end{abstract}

KeyWord: Haiti. Migration. Haitian Revolution

\section{Haití: Aspectos Socio-Históricos Internos y Emigración}

\section{Resumen}

Haití, un Estado fundado constitucionalmente en la igualdad entre negros y blancos, vive en el cotidiano una cruel división racial entre negros y mulatos, una compleja relación con los extranjeros y, a pesar de la inmensa riqueza geográfica y cultural, debilidad y corrupción institucional paralizan su desarrollo. Este texto se propone a un breve análisis socio-histórico, explicado de forma cronológica y lineal para facilitar el encadenamiento de los acontecimientos, a fin de dar subsidios para la comprensión de algunas de esas paradojas y de los motivos del gran número de haitianos que emigran de este país.

Palabras-clave: Haití. Migración. Revolución haitiana 